Available online on 15.08 .2020 at http://jddtonline.info
Open Access to Pharmaceutical and Medical Research
unrestricted non-commercial use, provided the original work is properly cited

Open $\odot$ Access

Research Article

\title{
Protective effects of Trigonella foenum-graecum crude extract over damage induced by Sreptozotocin diabetes rats
}

\author{
Dalila Bencheikh ${ }^{1,2 *}$, Seddik Khennouf ${ }^{1}$, Saliha Dahamna ${ }^{1}$ \\ ${ }^{1}$ Laboratory of Phytotherapy Applied to Chronic Diseases, Department of Biology and Animal Physiology, Faculty of Nature and Life Sciences, \\ University Ferhat Abbas Setif 1, Setif, 19000, Algeria \\ ${ }^{2}$ Department of biochemistry and microbiology, Faculty of Sciences, University of Mohamed Boudiaf, M'sila, 28000. Algeria
}

\begin{abstract}
The seeds of Trigonella foenum-graecum (fenugreek) are used for treatment of diabetes mellitus in traditional medicine. This paper examines the protection effects of fenugreek from the damage induced by streptozotocin diabetes rats. Tannins content of $T$. foenum-graecum was also estimated in vitro. Normoglycemic male Wistar rats, weighing 170-250 g, were selected and randomly divided into five groups (n=6): normal control, diabetic + TFGE $(200 \mathrm{mg} / \mathrm{kg})$, diabetic+ TFGE $(600 \mathrm{mg} / \mathrm{kg})$, diabetic + Glibil $(3 \mathrm{mg} / \mathrm{kg})$, untreated group. Diabetes was ind uced after a single intraperitoneal injection of streptozotocin $(50 \mathrm{mg} / \mathrm{kg}$ body weight) and Fenugreek was given every day via orogastric tube for 18 days. At the end of experiment, rats were sacarificed. Organ weight was estimated of all groups. Trigonella foenum-graecum administration significantly improved the polydipsia, polyphagia, and it also compensated weight loss of diabetic rats $(\mathrm{P}<0.05, \mathrm{P}<0.01)$. Moreover, fenugreek had a significant concentration of tannins (806.22 $\pm 0.036 \mu \mathrm{g}$ TAE/gE). The results revealed that fenugreek improves the damage in diabetic rats that in some ways validates the traditional use of this plant in treatment of diabetes.
\end{abstract}

Keywords: Antidiabetic activity, Protective effect, Streptozotocin, Tannins, Trigonella foenum-graecum

Article Info: Received 21 June 2020; $\quad$ Review Completed 18 July 2020; Accepted 27 July 2020; Available online 15 August 2020

Cite this article as: Bencheikh D, Khennouf S, Dahamna S, Protective effects of Trigonella foenum-graecum crude extract over damage induced by Sreptozotocin diabetes rats, Journal of Drug Delivery and Therapeutics. 2020; 10(4s):138-141 http://dx.doi.org/10.22270/jddt.v10i4-s.4256

*Address for Correspondence: Dalila Bencheikh, Laboratory of Phytotherapy Applied to Chronic Diseases, Department of Biology and Animal Physiology, Faculty of Nature and Life Sciences, University Ferhat Abbas Setif 1, Setif, 19000, Algeria

\section{INTRODUCTION}

Diabetes mellitus is a complex disease characterized by hyperglycemia and associated with insulin insufficiency or insensitivity of target organs to insulin. Hyperglycemia in diabetes produces the classical symptoms of polyuria, polydipsia, polyphagia and diabetes complications ${ }^{1}$ which occur due to the abnormalities in carbohydrate, fat, and protein metabolism ${ }^{2}$.

Streptozotocin (STZ) had toxic effects on islet beta cells that is why it widely used to induce insulin-dependent diabetes mellitus in experimental animals 3, 4. STZ produced severe lesions in pancreas, liver, kidney of progressively increased with time after treatment from seven to forty two days ${ }^{5}$. The acute and chronic cellular injury, carcinogenesis, teratogenesis and mutagenesis were considered as biological actions of STZ ${ }^{6}$.

Medicines from plant sources have played a vital role in the healthcare of the population. The crude extracts of varieties of plants have been used in clinical practice from long time. Because of diversity in phytoconstituents with unknown biological effect $7,8,9$.

Trigonella foenum-graecum L.(Fenugreek) is an annual plant of the Fabaceae family. It has long been cultivated in the
Mediterranean area, in India and in North Africa 10. Fenugreek is an annual grass with round stem, smooth, upright, from 20 to $50 \mathrm{~cm}$ with characteristic odor. Principal components of Fenugereek are mucilage, saponins, diosgenin, flavonoids, protids, prolamin, essential oil, nicotinic acid, mineral elements:iron, phosphorus, calcium., vitamins, A, B1, C, alkaloids (trigonelline...), choline... ${ }^{11}$.

This plant regarded as a panacea on popular medical. The use of fenugreek is common in various forms: seed decoctions, flour mixed with honey, or the vinegar. The most properties are polishing substance, anabolisant, aperitif, emollient, febrifuge, galactagogue, hypoglycemic, tonic 11. Therefore, this study was conducted to assess the tannins content and to evaluate the anti-diabetic effect of Trigonella foenum-graecum $L$ crude extract in normal and diabetic rats and their role to improve the damage over diabetes (polyuria, polyphagia and organs weight).

\section{MATHERIALS AND METHODS}

\section{Reagents and standards}

Methanol (MeOH), Tannic acid, Streptozotocin. The products used were purchased from Merck and Sigma. 


\section{Plant samples}

Seeds of Trigonella feonum-gracum (Fenugrec, elhalba) were collected from Setif, Algeria. The plant was authentified by Pr. Laouer Hocine (University FerhatAbbass, Setif-1, Algeria). The plant samples were air dried in shadow and powdered.

\section{Extraction of plant phenols}

Extractions of Trigonella feonum-gracum seeds polyphenols was carried out according to 12 with slight modification. 1 liter of $85 \%$ methanol was added to $100 \mathrm{~g}$ of powdered plant material. After 3days, the filtration of the residue obtained was re-extracted with 1 liter of $50 \%$ methanol for $24 \mathrm{~h}$. Under reduced pressure (at $40 \mathrm{C}^{\circ}$ ) using a rotary evaporator, the first and the second extractions were concentrated to obtain methanolic extract of Trigonella feonum-gracum (TFGE). Then, the extract were stored at $-20{ }^{\circ} \mathrm{C}$ until use

\section{Animals}

Male adult albino rats weighing 170-280 g obtained from Pasteur Institute (Algiers, Algeria) were maintained in an airconditioned animal room $\left(25 \pm 2^{\circ} \mathrm{C}\right)$, with $12 / 12 \mathrm{~h}$ light/dark cycle and given free access to water and food for 7 days, prior to experiments.

\section{In vitro: Determination of tannins content}

Tannins content was estimated by the method of 13 . Briefly a volume of plant extract was diluted to give a concentration of total polyphenols approximately $500 \mu \mathrm{g} / \mathrm{ml}$ and mixed with an equal volume of haemolysed sheep blood (Absorbance equal to 1.6), after 10 minutes this solution was centrifuged for 20 minutes and the absorbance of the supernatant was measured at $576 \mathrm{~nm}$ and the effectiveness of the precipitation of the solutions tested is expressed as $\mu \mathrm{g}$ tannic acid equivalent/ g extract.

\section{Experimental induction of diabetes}

Anti-diabetic activity of $T$. feonum-gracum extracts was evaluated by Streptozotocin induced rats according to the method of 14 with slight modifications. By single intraperitoneal injection of a freshly prepared streptozotocin (STZ) solution $(50 \mathrm{mg} / \mathrm{kg})$ to overnight fasted rats, diabetes was induced. Rats with blood glucose levels $\geq 250 \mathrm{mg} / \mathrm{dl}$ were considered diabetic and were used for the study.

\section{Experimental designs}

Male Wistar rats weighing 170-280 g were divided into five equal groups $(n=6)$.
Group1: (Control), received distilled water

groups 2,3: treated with TFGE extract $(200,600 \mathrm{mg} / \mathrm{kg}$ respectively)

group 4: received glibenclamide or Glibil used as a standard oral hypoglycemic agent $(3 \mathrm{mg} / \mathrm{kg})$,

group 5: untreated group did not receive any thing

For 18 days, the treatment was given every day via orogastric tube. After sacrificed of animals, all organs were removed. The organs, the food and water intake were also measured to determine food, water intake and the change in the weight of organs and were statistically analyzed.

\section{Statistical analysis}

Data were performed using Graph Pad Prism (version 5.01 for Windows) and were analyzed by One-way analysis of ANOVA followed by Tukey's test. Whereas in vitro experiments were calculated as mean \pm SD $(n=3)$. The $\mathrm{P}<$ 0.05 was considered statistically significant.

\section{RESULTS AND DISCUSSION}

\section{Tannins content}

Based on the absorbance value of the plant extract solution reacting with haemolysed sheep blood and compared with the absorbance values of standard solutions of Tannic acid the relative contents of tannins in TFGE was estimated as $806,22 \pm 0,036 \mu \mathrm{g}$ TAE/gE.

\section{Water and food intake}

The present study was designed to observe the effects of streptozotocin (STZ)-induced diabetes and studying the association between the increase of polydipsia, polyphagia and diabetes.

Table 1 shows significant differences in water and food intake in the different experimental groups. The consumptions of water and food in normal rats were $496.6 \pm 5.77 \mathrm{ml} /$ day; $198.55 \pm 5.95 \mathrm{~g} /$ day, respectively. Whereas, the water and food intake values in untreated rats was $1070 \pm 14.14 \mathrm{ml} /$ day and $225.95 \pm 21.45 \mathrm{~g} /$ day, respectively. TFGE doses (200mg/kg and $600 \mathrm{mg} / \mathrm{kg}$ ) administration compensated the reduced polydipsia $(605.3 \pm 7.07 \mathrm{ml} /$ day; $535 \pm 7.07 \mathrm{ml} /$ day respectively) and hyperphagia $\quad(216.25 \pm 11.75 \mathrm{~g} /$ day; $\quad 198.6 \pm 5.9 \mathrm{~g} /$ day respectively). Glibil group showed a significant reduce of polydipsia and hyperphagia $(\mathrm{P}<0.001 ; \mathrm{P}<0.01)$.

Table 1: Effects of TFGE administered on water intake and food intake of normal and diabetic rats

\begin{tabular}{|c|c|c|c|c|c|}
\hline & Control & $\begin{array}{c}\text { TFGE } \\
(200 \mathrm{mg} / \mathrm{kg})\end{array}$ & $\begin{array}{c}\text { TFGE } \\
(600 \mathrm{mg} / \mathrm{kg})\end{array}$ & $\begin{array}{c}\text { Glibil } \\
(3 \mathrm{mg} / \mathrm{kg})\end{array}$ & Untreated \\
\hline $\begin{array}{l}\text { Water intake } \\
\text { (ml/day) }\end{array}$ & $496.6 \pm 5.77$ & $605.3 \pm 7.07^{* * *}$ & $535 \pm 7.07^{*}$ & $715 \pm 7.17^{* * *}$ & $1070 \pm 14.14^{* * *}$ \\
\hline $\begin{array}{l}\text { Food intake } \\
\text { (g/day) }\end{array}$ & $198.55 \pm 5.95$ & $216.25 \pm 11.75^{* * *}$ & $198.6 \pm 5.9 \mathrm{~ns}$ & $207.85 \pm 3.35^{* *}$ & $225.95 \pm 21.45^{* * *}$ \\
\hline
\end{tabular}

The values present the mean \pm SEM for six rats in each group (ns: no significant difference, ${ }^{*} \mathrm{p}<0.05,{ }^{* *} \mathrm{p}<0.01,{ }^{* * *} \mathrm{p}<0.001$ ) compared to control group.

In the present study, streptozotocin was used in a dose of 50 $\mathrm{mg} / \mathrm{kg}$ body weight intraperitoneal injection for producing hyperglycaemia in accordance with 15 used the same dose of STZ but intravenously in rats. While ${ }^{16}$ used high dose of STZ
(90 mg/kg body weight intraperitoneally in rats). The selection of higher dose was not tolerated and survive for rats and should adopted the lower dose. Traditional medicine use the food tannins because of it's good 
preventive on human health. Also, some tannins are considered as antioxidants. The most properties of tannins are cardio-protective, anti-inflammatory, anti-carcinogenic and antimutagenic, and others. They act as free radical scavengers or activate antioxidant enzymes. Also, in diabetic rats, tannins have been considered as anti-hyperglycemic agents ${ }^{17}$. The phenolic compounds could reduce glycemia by reduction in the absorption of nutrients (food intake) ${ }^{18}$.

\section{Organs weight}

The results showed that organs weight changed slightly compared to control group (Table2).

Heart and lungs weights of untreated or diabetic rats $(0.65 \pm 0.03 \mathrm{~g} ; 1.23 \pm 0.05 \mathrm{~g}$ respectively) showed a significant decrease $(\mathrm{P}<0.05)$ as compared to normal control rats $(0.88 \pm 0.16 \mathrm{~g} ; 1.68 \pm 0.27 \mathrm{~g}$ respectively). Treatment with two doses extracts produced no significant change of the testicles $(2.66 \pm 0.6 \mathrm{~g} ; 2.51 \pm 0.28 \mathrm{~g}$ respectively) and stomach (1.53 $\pm 0.015 \mathrm{~g} ; 1.41 \pm 0.11 \mathrm{~g}$ respectively) whereas, the values of untreated group was being $(2.43 \pm 0.05 \mathrm{~g} ; 1.40 \pm 0.10 \mathrm{~g})$ respectively. Concerning pancreas the present data showed a higher significant decrease $(\mathrm{P}<0.001)$ in untreated group when compared with control group (Table 2). So, all the treatment with two doses extract showed a detectable elevation of all organs weight in diabetic rats.

Glibil treated group were reported to have measurable effect on organs weight (Heart, lungs, stomach, spleen, testicles), Whereas, Untreated group remained the lower values.

Table 2: Organs weight changes in the treated and untreated animals (g)

\begin{tabular}{lccccc}
\hline & Control & $\begin{array}{c}\text { TFGE } \\
(200 \mathrm{mg} / \mathrm{kg})\end{array}$ & $\begin{array}{c}\text { TFGE } \\
(600 \mathrm{mg} / \mathrm{kg})\end{array}$ & $\begin{array}{c}\text { Glibil } \\
(3 \mathrm{mg} / \mathrm{kg})\end{array}$ & Untreated \\
\hline Heart & $0.88 \pm 0.16$ & $0.66 \pm 0.08^{*}$ & $0.63 \pm 0.07^{*}$ & $0.67 \pm 0.11^{*}$ & $0.65 \pm 0.03^{*}$ \\
Liver & $5.17 \pm 0.94$ & $4.01 \pm 1.29^{*}$ & $4.09 \pm 1.06^{*}$ & $4.33 \pm 0.45^{* *}$ & $4.15 \pm 0.7^{* *}$ \\
Testicles & $3.14 \pm 0.22$ & $2.66 \pm 0.6 \mathrm{~ns}$ & $2.51 \pm 0.28 \mathrm{~ns}$ & $2.9 \pm 0.37 \mathrm{~ns}$ & $2.43 \pm 0.05 \mathrm{~ns}$ \\
Kidneys & $1.80 \pm 0.06$ & $1.66 \pm 0.13 \mathrm{~ns}$ & $1.26 \pm 0.08^{* * *}$ & $1.53 \pm 0.02 \mathrm{~ns}$ & $1.5 \pm 0.14^{* * *}$ \\
Spleen & $1.02 \pm 0.10$ & $0.95 \pm 0.14 \mathrm{~ns}$ & $0.74 \pm 0.11^{*}$ & $0.6 \pm 0.01^{* *}$ & $0.61 \pm 0.07^{* * *}$ \\
Stomach & $1.55 \pm 0.19$ & $1.53 \pm 0.015 \mathrm{~ns}$ & $1.41 \pm 0.11 \mathrm{~ns}$ & $1.43 \pm 0.13 \mathrm{~ns}$ & $1.40 \pm 0.10 \mathrm{~ns}$ \\
Pancreas & $0.25 \pm 0.03$ & $0.20 \pm 0.02 \mathrm{~ns}$ & $0.15 \pm 0.02^{*}$ & $0.14 \pm 0.02^{* *}$ & $0.12 \pm 0.02^{* * *}$
\end{tabular}

Value are mean \pm S.E.M (n=6) (ns: no significant difference, ${ }^{*} p<0.05,{ }^{* *} p<0.01,{ }^{* * *} p<0.001$ ) compared to control group.

A notable significant decrease of liver in untreated group $(\mathrm{P}<$ 0.001) when compared to control one (Table 2). The recorded values of diabetic rats showed a high decrease in kidneys weight $(0.85 \pm 0.14 \mathrm{~g})$ as compared with the normal control rats $(1.80 \pm 0.06 \mathrm{~g})$. An increase (hypertrophy) in the weight of liver in proportion to the body weight was observed in untreated group were compared with control group despite the fact that the mean weight of all the animals in treated group with TFGE, Glibil and untreated groups decreased (Table 3).

Table 3: Comparison between organ weight in the treated and untreated animals in grams to weight of animal in kilograms of rats $(\mathrm{X} \pm$ S.E.M.).

\begin{tabular}{llllll}
\hline & Control & TFGE & TFGE \\
& & $(200 \mathrm{mg} / \mathrm{kg})$ & $\begin{array}{l}\text { Glibil } \\
(600 \mathrm{mg} / \mathrm{kg})\end{array}$ & $\begin{array}{l}\text { Untreated } \\
(3 \mathrm{mg} / \mathrm{kg})\end{array}$ & \\
\hline Body weight & $257.14 \pm 13.16$ & $209.48 \pm 12$ & $212 \pm 14.06$ & $226.87 \pm 8.12$ & $202.40 \pm 2.68$ \\
Liver & $19.67 \mathrm{~g} / \mathrm{kg}$ & $19.14 \mathrm{~g} / \mathrm{kg}$ & $19.26 \mathrm{~g} / \mathrm{kg}$ & $19.08 \mathrm{~g} / \mathrm{kg}$ & $20.50 \mathrm{~g} / \mathrm{kg}$ \\
Kidneys & $7 \mathrm{~g} / \mathrm{kg}$ & $7.92 \mathrm{~g} / \mathrm{kg}$ & $6.12 \mathrm{~g} / \mathrm{kg}$ & $6.74 \mathrm{~g} / \mathrm{kg}$ & $7.41 \mathrm{~g} / \mathrm{kg}$ \\
Pancreas & $0.97 \mathrm{~g} / \mathrm{kg}$ & $0.95 \mathrm{~g} / \mathrm{kg}$ & $0.70 \mathrm{~g} / \mathrm{kg}$ & $0.61 \mathrm{~g} / \mathrm{kg}$ & $0.59 \mathrm{~g} / \mathrm{kg}$
\end{tabular}

The selective destruction and disappearance of insulinproducing cells ( $\beta$ cells) attributed to the decrease in the weight of pancreas 19, 20. Alkylation of DNA, produced hyperglycaemia and necrotic lesions was caused by injurious effects of STZ leads to loss of organs weight .The results of the present study are in agreement with the findings of 5,21, 22. Also, 23 concluded that the reduction in body weight was associated with increase (hypertrophy) in the relative weight of kidney and liver whereas the pancreas weight was unaffected.

\section{CONCLUSION}

The inclusion of the different two doses of TFGE $(200 \mathrm{mg} / \mathrm{kg}$, $600 \mathrm{mg} / \mathrm{kg}$ ) resulted in increased weight near to normal level. Also, TFGE showed a considerable effect on the water and food intake. The ameliorating effects of Trigonella foenum-graecum could be related to its tannins constituents. In conclusion, using Fenugreek seeds exhibits preventive effects against diabetes which, in turn, validates the traditional use of the plant in the treatment of diabetes mellitus. Further comprehensive chemical and pharmacological investigations with isolated active principles of the plant may shed more light on the use of fenugreek for protection in diabetes. 


\section{CONFLICT OF INTEREST}

The authors declare no conflict of interest.

\section{ACKNOWLEDGEMENTS}

This work was supported by the Algerian Ministry of Higher Education and Scientific Research (MERS).

\section{REFERENCES}

1. Freeman VS. Carbohydrates. In: Clinical Chemistry, Principles, Procedures, Correlations. Bishop, M.L., Fody, E.P. and Schoeff, L. eds. 5th ed., Lippincott Williams and Wilkins; 2005. P. 262-281.

2. Craig ME, Hattersley A, Donaghue KC. Definition, epidemiology and classification of diabetes in children and adolescents. Pediatr Diabetes, 2009; 10: 3-12.

3. Punithavathi V R, Anuthama R., Prince P S. Combined treatment with naringin and vitamin $\mathrm{C}$ ameliorates streptozotocin-induced diabetes in male Wistar rats. J Appl Toxicol, 2008; 28(6):806-13.

4. Fadillioglu E, Kurcer Z, Parlakpinar H, Iraz M, Gursul C. Melatonin treatment against remote open injury induced by renal ischemia reperfusion injury in diabetes mellitus. Arch Pharm Res, 2008; 31(6):705-12.

5. Piyachaturawat P, Poprasit J, Glinsukon T, Warichanon C. Gastric mucosal lesions in Streptozotocin diabetic rats. Cell Biol. Intern. Rep, 1988; 12(1):53-63.

6. Magee P N, Swann P F. Nitroso compounds. Br Med Bull, 1969; 25: 240-44.

7. Mapanga RF, Musabayane CT. The renal effects of blood glucoselowering plant-derived extracts in diabetes mellitus-an overview. Ren F fail, 2010; 32:132-138.

8. Paler ME, Haller C, McKinney PE. Adverse events associated with dietary supplements : an observational study. Lancet, 2003; 361:101-106.

9. Pitter MH, Ernst E. Systematic review: hepatotoxic events associated with herbal medicinal products. Aliment Pharmacol Ther, 2003; 18:451-471.

10. Rosengarten JrF. The book of species. Livington Publishing Company Wynewood PA, USA. 1969.

11. Baba AÏSSA F. Encyclopédie des plantes utiles. Flore Méditerranéenne (Maghreb, Europe méridionale). Substances végétales d'Afrique, d'Orient et d'Occident. Ed.10, avenue Abderrahmane Mira BE0, Alger; 2011. P. 259-260.

12. Markham KR. Techniques of flavonoid identification (Chapter 1 and 2). London: Academic press; 1982. P. 1-113.
13. Bate-Smith E C. Haemanalysis of tannins, the concept of relative astringency. Phytochemistry, 1973; 12:907-912.

14. Andrade-Cetto A, Wiedenfeld $\mathrm{H}$, Revilla MaC, Islas $\mathrm{S}$. Hypoglycemic effect of Equisetum myriochaetum aerial parts on streptozotocin diabetic rats. J Ethnopharmacol, 2000; 72: 129133.

15. Oscika TM, Yu Y, Panagiotopoulos S, Clavant SP Kirizis Z, Pike RN, Pratt LM, Russo LM, Kemp B E, Camper WD, Jerums G. Prevention of albuminuria by aminoguanidine or ramipril in streptozotocin-induced diabetic rats is associated with the normalization of glomerular protein kinase C. Diabetes, 2000; 49(1):87-93.

16. Mozaffari MS, Warren BK, Russell CM, Schaffer SW. Renal function in the non-insulin dependent diabetic rat: effect of unilateral nephrectomy. J Pharmacol Toxicol Methods, 1997; 37(4):197-203.

17. Pinent M, Blay M, Blade MC, Salvado MJ, Arola L, Ardevol A. Grape seedderived procyanidins have an antihyperglycemic effect in streptozotocin-induced diabetic rats and insulinomimetic activity in insulinsensitive cell lines. Endocrinology,2004; 145, 4985-4990.

18. Kao YH, Hiipakka RA, Liao S. Modulation of endocrine systems and food intake by green tea epigallocatechin gallate. Endocrinology, 2000; 141:980-987.

19. Kim JD, Kang SM, Seo BI, Choi HY, Choi HS, Ku SK. Anti-diabetic activity of SMK001, a poly herbal formula in streptozotocininduced diabetic rats: therapeutic study. Biol Pharm Bull, 2006; 29(3):477-82.

20. Heidari Z, Mahmoudzadeh-Sagheb H, Moudi B. A quantitative study of sodium tungstate protective effect on pancreatic beta cells in streptozotocin-induced diabetic rats. Micron, 2008; $39(8): 1300-5$

21. Habibuddin M, Daghriri H A, Humaira T, Al-Qahtani MS, Hefzi A A. Antidiabetic effect of alcoholic extract of Caralluma sinaica L. on streptozotocin-induced diabetic rabbits. J. Ethnopharmacol, 2008; 117(2):215-20.

22. Lee SI, Kim JS, Oh SH, Park KY, Lee HG, Kim SD. Antihyperglycemic effect of Fomitopsis pinicola extracts in streptozotocin-induced diabetic rats. J Med Food, 2008; 11(3):518-24.

23. Zafar M, Naeem-Ul-Hassan Naqvi S. Effects of STZ-Induced diabetes on the relative weights of kidney, liver and pancreas in albino rats: a comparative study. Int J Morphol, 2010; 28(1):135142. 